\title{
Structure and Optimization of Checkpoint Inhibitors
}

\author{
Sarah L. Picardo ${ }^{1, *}$, Jeffrey Doi ${ }^{2}$ and Aaron R. Hansen ${ }^{1}$ \\ Department of Medical Oncology, Princess Margaret Cancer Centre, 700 University Avenue, \\ Toronto, ON M5G 1X6, Canada; aaron.hansen@uhn.ca \\ 2 Department of Pharmacy, Princess Margaret Cancer Centre, 610 University Avenue, \\ Toronto, ON M5G 2M9, Canada; jeffrey.doi@uhn.ca \\ * Correspondence: sarah.picardo@uhn.ca
}

Received: 20 November 2019; Accepted: 16 December 2019; Published: 21 December 2019

check for updates

\begin{abstract}
With the advent of checkpoint inhibitor treatment for various cancer types, the optimization of drug selection, pharmacokinetics and biomarker assays is an urgent and as yet unresolved dilemma for clinicians, pharmaceutical companies and researchers. Drugs which inhibit cytotoxic T-lymphocyte associated protein-4 (CTLA-4), such as ipilimumab and tremelimumab, programmed cell death protein-1 (PD-1), such as nivolumab and pembrolizumab, and programmed cell death ligand-1 (PD-L1), such as atezolizumab, durvalumab and avelumab, each appear to have varying pharmacokinetics and clinical activity in different cancer types. Each drug differs in terms of dosing, which becomes an issue when drug comparisons are attempted. Here, we examine the various checkpoint inhibitors currently used and in development. We discuss the antibodies and their protein targets, their pharmacokinetics as measured in various tumor types, and their binding affinities to their respective antigens. We also examine the various dosing regimens for these drugs and how they differ. Finally, we examine new developments and methods to optimize delivery and efficacy in the field of checkpoint inhibitors, including non-fucosylation, prodrug formations, bispecific antibodies, and newer small molecule and peptide checkpoint inhibitors.
\end{abstract}

Keywords: checkpoint inhibitors 1; protein structure 2; pharmacokinetics 3; drug optimization 4

\section{Introduction}

Checkpoint inhibitors (CPIs) induce an anti-tumor immune response by antagonizing suppressive immune checkpoint regulatory pathways. The recognized function of these immune checkpoints is to modulate or prevent autoimmune responses and or auto-inflammation. The advent of antibodies targeting programmed cell death protein-1 (PD-1), programmed cell death protein ligand-1 (PD-L1) and cytotoxic T-lymphocyte associated protein-4 (CTLA-4) has led to the development of drugs targeting these pathways in the last 10 years. However, their variable pharmacokinetics and response rates has led to efforts to optimize these drugs, as well as to develop new drugs targeting other checkpoint pathways. Here we examine the structure and mechanism of action of these drugs and human pharmacokinetics in terms of their binding affinities, clearance, and the significance of dosing regimens. In addition, we describe efforts to enhance the delivery and formulation of CPIs, while attempting to minimize the immune-related adverse events (irAEs) associated with these treatments. 


\section{CTLA-4, PD-1 and PD-L1 Proteins and Antibodies}

\subsection{Proteins}

\subsubsection{CTLA-4}

CTLA-4 was first described in 1987 as "a new member of the immunoglobulin superfamily" [1]. It is a 223 amino acid protein which is expressed on activated T cells co-expressing CD28 [2] and has extracellular, transmembrane and intracellular components. Its ligands are CD80 (B7-1) and CD86 (B7-2), found on antigen presenting cells and T-regulatory (T-reg) cells, with binding causing downregulation of activated $\mathrm{T}$ cell activity and upregulation of suppressive T-reg function. The importance of CTLA-4 is demonstrated in CTLA-4-knockout mice, who develop early and catastrophic immune hyperactivation causing myocarditis and pancreatitis, and die by 3-4 weeks of age [3].

\subsubsection{PD-1 and PD-L1}

The PD-1 protein is a 288 amino acid protein which is primarily expressed on T cells, but also on other immune cells, such as B cells, natural killer T cells, and monocytes. It was first identified at a gene level in murine cell lines and was initially thought to be involved in apoptosis, as its expression was induced when thymocyte cell death was induced [4]. Subsequently, it was found to suppress immune responses, and, in particular, it is hypothesized that PD-1 suppresses anti-self-responses [5,6]. This theory is supported by the fact that PD-1 induction is suppressed in the presence of "foreign" antigens such as lipopolysaccharide (LPS) and a stimulatory CpG-containing oligodeoxynucleotide CpG1826 [7]. The protein itself has an intracellular domain, a hydrophobic transmembrane domain and an extracellular immunoglobulin domain which is folded into a $\beta$-strand "sandwich" connected by a disulphide bridge. The intracellular domain, or cytoplasmic tail, contains an N-terminal sequence which forms an immunoreceptor tyrosine-based inhibition motif, as well as a C-terminal sequence which forms an immunoreceptor tyrosine-based switch motif. The murine and human forms of PD-1 share a $62 \%$ identical sequence, but there are significant differences in the ligand-binding sites, including alterations in size, polarity and charge [8].

The PD-1 protein has two major ligands-PD-L1 and PD-L2. Both ligands contain an N-terminal domain, which binds to PD-1, and a C-terminal domain, the function of which is as yet unknown. Both domains have an immunoglobulin-like fold forming a $\beta$-strand sandwich similar to that of PD-1 and are joined by a short linker. Nuclear magnetic resonance characterization suggests that PD-L1 proteins form homodimers, exposing the hydrophobic PD-1 binding sites, although whether this occurs in vivo remains unclear [8-10]. The PD-L2 molecule has a similar structure, with two immunoglobulin domains and a linker region, with most of the residues in the binding interfaces of both ligands conserved [11].

The binding of human PD-1 and PD-L1 proteins forms a 1:1 complex and induces a conformational change in PD-1, with the closure of the $\mathrm{CC}^{\prime}$ loop around PD-L1 and formation of hydrogen bonds, which are hypothesized to stabilize the complex and cause re-arrangements of the PD-1 protein $[10,12]$. The binding regions contain both hydrophobic and polar sites, with the majority of the interaction occurring in the front strands of both proteins using the large hydrophobic surfaces of the immunoglobulin-V-type domains; the complex between PD-1 and PD-L2 is thought to be similar, although much of this work is only in murine proteins [11].

\subsubsection{Significance in Cancer Immunity}

CTLA-4 was the first checkpoint molecule targeted in cancer treatment, initially in melanoma with dramatic results, and subsequently in other cancer types. Its significance in anti-tumor immunity was described over 20 years ago in murine models where blockade of CTLA-4 caused tumor rejection both in established tumors and with secondary exposure to tumor cells [13]. PD-1 is mainly expressed on immune cells, in particular T lymphocytes, as well as B lymphocytes, NK cells, dendritic cells and 
monocytes, and its expression can be induced by many factors, including interleukins, infectious agents and LPS [14-16]. As described above, its main function is in immune suppression; therefore, in tumors, it can have the detrimental effect of decreasing anti-tumor immunity, particularly because many cancers develop the capability to express the PD-L1 ligand. On presentation of an antigen to a T lymphocyte, a typical T-cell response involves binding the antigen to the specific T-cell receptor, expansion of this $\mathrm{T}$ cell clone and, finally, an effector phase of the response. The co-receptors CD28 and CD3 are involved in the induction of this response. Specifically, in the tumor microenvironment, neoantigens from cancer cells are released, captured and processed by antigen-presenting cells. Antigen presentation to T cells must be accompanied by a secondary signal mechanism in order for $\mathrm{T}$ cells to be primed and activated. This secondary signal can be via cytokines, such as IL-12 and type 1 interferon, factors released by dying cancer cells or via the gut microbiota $[17,18]$. Both CTLA-4 and PD-1 suppress CD28-mediated pathways; PD-1 does this by the activation of phosphatidylinositol-3-kinase which in turn inhibits Akt phosphorylation, thereby suppressing T-cell activation, and also inhibits glycolytic pathways, thereby decreasing cellular metabolism [19]. CTLA-4 binds to its B7 ligands with a much higher affinity than CD28, preventing T-cell stimulation.

Tumor cells in many cancer types express PD-L1 and therefore can activate this pathway to escape immune surveillance. The expression of PD-L1 by tumor cells may be an adaptive response to anti-tumor immune response, with PD-L1 expression co-localized with tumor-infiltrating lymphocytes and IFN- $\delta$, an inflammatory cytokine [20]. However, the clinical significance of PD-L1 expression is tumor histology-specific, with some cancers demonstrating improved outcomes with high PD-L1 expression, while, in other tumors, PD-L1 expression does not correlate with better survival [21-26]. The expression of PD-1 and PD-L1 in tumors may also be heterogeneous both intra-tumorally and between primary and metastatic tumor sites [27-30].

\subsection{Monoclonal Antibodies}

\subsubsection{Anti-CTLA-4}

Ipilimumab, which binds to CTLA-4, was the first CPI to be licensed in 2011, and was initially used for the treatment of metastatic melanoma but is now indicated in multiple tumor types. It has a high surface area at its binding site and has a dissociation constant of $5.25 \mathrm{nM}$, with a large surface area buried at its binding surface with CTLA-4 [31] (Table 1). Tremelimumab is another monoclonal antibody targeting CTLA- 4 but has not yet been licensed for any indication, although it has orphan drug status for treatment of mesothelioma. Tremelimumab is an IgG2 antibody; this subtype is thought to have less complement activation and antibody-dependent cell-mediated cytotoxicity [32]. It is currently in ongoing clinical trials, in particular in combination with durvalumab [33]. 
Table 1. Checkpoint inhibitors, their pharmacokinetic and dosing profiles and indications.

\begin{tabular}{|c|c|c|c|c|c|c|c|c|c|c|}
\hline Agent & Type & Antigen & Clearance & $\begin{array}{c}\text { Dissociation } \\
\text { Constant// } \\
\text { Binding Affinity }\end{array}$ & Half-Life & Indications & $\begin{array}{l}\text { Companion/ Complementary } \\
\text { Diagnostic Assay }\end{array}$ & Dosing & $\begin{array}{l}\text { Year First } \\
\text { Licensed }\end{array}$ & $\begin{array}{l}\text { Pharmaceutica } \\
\text { Company }\end{array}$ \\
\hline Ipilimumab & $\begin{array}{l}\text { IgG1 human } \\
\text { antibody }\end{array}$ & CTLA-4 & $\begin{array}{c}\text { Stable clearance } \\
\text { over doses } \\
0.3-10 \mathrm{mg} / \mathrm{kg} \\
\end{array}$ & $\begin{array}{c}\text { Dissociation } \\
\text { constant } 5.25 \mathrm{nM}\end{array}$ & 15.4 days & $\begin{array}{l}\text { Melanoma, renal cell carcinoma, } \\
\text { MSI-high colorectal carcinoma }\end{array}$ & None & $\begin{array}{l}\text { Weight-based dosing } \\
\quad(1-10 \mathrm{mg} / \mathrm{kg})\end{array}$ & 2011 & $\begin{array}{l}\text { Bristol Myers } \\
\text { Squibb }\end{array}$ \\
\hline Tremelimumab & $\begin{array}{l}\text { IgG2 human } \\
\text { antibody }\end{array}$ & CTLA- 4 & $\begin{array}{l}\text { Stable clearance } \\
\text { over doses } \\
10-15 \mathrm{mg} / \mathrm{kg}\end{array}$ & $\begin{array}{c}\text { Binding affinity } \\
0.28 \mathrm{nM}\end{array}$ & 22 days & None as yet & None & $\begin{array}{c}\text { Weight-based dosing } \\
\text { (3-15 mg/kg) or fixed } \\
\text { dosing }(75 \mathrm{mg})\end{array}$ & $\begin{array}{r}\text { Not yet } \\
\text { licensed }\end{array}$ & AstraZeneca \\
\hline Nivolumab & $\begin{array}{l}\text { IgG4 human } \\
\text { antibody }\end{array}$ & PD-1 & $\begin{array}{l}\text { Linear clearance } \\
\text { over doses of } \\
0.1-20 \mathrm{mg} / \mathrm{kg}\end{array}$ & $\begin{array}{l}\text { Dissociation } \\
\text { constant } 1.45 \mathrm{nM}\end{array}$ & 25 days & $\begin{array}{l}\text { Melanoma, non-small cell lung cancer, } \\
\text { renal cell carcinoma, small cell lung } \\
\text { cancer, head and neck cancer, } \\
\text { hepatocellular carcinoma, Hodgkin } \\
\text { lymphoma, urothelial cancer, MSI-high } \\
\text { or mismatch repair-deficient } \\
\text { colorectal cancer }\end{array}$ & $\begin{array}{l}\text { Dako 28.8 Pharm.Dx assay } \\
\text { (complementary) }\end{array}$ & $\begin{array}{l}\text { Weight-based dosing } \\
(1-3 \mathrm{mg} / \mathrm{kg} \text { ) or flat dosing } \\
(240 \mathrm{mg})\end{array}$ & 2014 & $\begin{array}{l}\text { Bristol Myers } \\
\text { Squibb }\end{array}$ \\
\hline Pembrolizumab & $\begin{array}{l}\text { IgG4 human } \\
\text { antibody }\end{array}$ & PD-1 & $\begin{array}{l}\text { Linear clearance } \\
\text { over doses } \\
1-10 \mathrm{mg} / \mathrm{kg}\end{array}$ & $\begin{array}{l}\text { Dissociation } \\
\text { constant } 29 \mathrm{pM}\end{array}$ & 22 days & $\begin{array}{l}\text { Melanoma, non-small cell lung cancer, } \\
\text { renal cell carcinoma, small cell lung } \\
\text { cancer, Hodgkin lymphoma, primary } \\
\text { mediastinal large B-cell lymphoma, } \\
\text { Merkel cell carcinoma, hepatocellular } \\
\text { carcinoma, gastric cancer, renal cell } \\
\text { carcinoma, endometrial carcinoma, } \\
\text { cervical cancer, head and neck cancers, } \\
\text { urothelial carcinoma, } \\
\text { gastric/GEJ/esophageal cancers, } \\
\text { mismatch repair deficient tumors }\end{array}$ & $\begin{array}{l}\text { Dako 22C3 Pharm.Dx } \\
\text { (companion for non-small cell } \\
\text { lung cancer, gastric or } \\
\text { gastroesophageal junction } \\
\text { adenocarcinoma, cervical } \\
\text { cancer, urothelial carcinoma, } \\
\text { head and neck squamous cell } \\
\text { carcinoma, and esophageal } \\
\text { squamous cell carcinoma) }\end{array}$ & Fixed dosing $(200 \mathrm{mg})$ & 2014 & Merck \\
\hline Atezolizumab & $\begin{array}{l}\text { IgG1 human } \\
\text { antibody }\end{array}$ & PD-L1 & $\begin{array}{l}\text { Linear clearance } \\
\quad \text { over doses } \\
1-20 \mathrm{mg} / \mathrm{kg}\end{array}$ & $\begin{array}{l}\text { Binding affinity } \\
971 \AA 2\end{array}$ & 27 days & $\begin{array}{l}\text { Urothelial carcinoma, non-small cell } \\
\text { lung cancer, triple-negative breast cancer, } \\
\text { small cell lung cancer }\end{array}$ & $\begin{array}{l}\text { Ventana SP142 (companion for } \\
\text { urothelial carcinoma and } \\
\text { triple-negative breast } \\
\text { carcinoma) }\end{array}$ & $\begin{array}{l}\text { Fixed dosing }(840 \mathrm{mg}, \\
1200 \mathrm{mg}, 1680 \mathrm{mg})\end{array}$ & 2016 & Genentech \\
\hline Avelumab & $\begin{array}{l}\text { IgG1 human } \\
\text { antibody }\end{array}$ & PD-L1 & $\begin{array}{l}\text { Linear clearance } \\
\text { over doses } \\
1-20 \mathrm{mg} / \mathrm{kg}\end{array}$ & $\begin{array}{l}\text { Binding affinity } \\
875.4 \text { A2 }\end{array}$ & 6 days & $\begin{array}{l}\text { Merkel cell carcinoma, urothelial } \\
\text { carcinoma, renal cell carcinoma }\end{array}$ & None & $\begin{array}{c}\text { Fixed dosing }(800 \mathrm{mg} \text { ) or } \\
\text { weight-based dosing } \\
(10 \mathrm{mg} / \mathrm{kg})(\text { not Food and } \\
\text { Drug Administration (FDA) } \\
\text { approved) }\end{array}$ & 2017 & $\begin{array}{c}\text { EMD } \\
\text { Serono/Pfizer }\end{array}$ \\
\hline Durvalumab & $\begin{array}{l}\text { IgG1 human } \\
\text { antibody }\end{array}$ & PD-L1 & $\begin{array}{l}\text { Linear clearance } \\
\text { at doses higher } \\
\text { than } 3 \mathrm{mg} / \mathrm{kg}\end{array}$ & $\begin{array}{l}\text { Dissociation } \\
\text { constant } 667 \mathrm{pM}\end{array}$ & 18 days & $\begin{array}{c}\text { Urothelial carcinoma, non-small cell } \\
\text { lung cancer }\end{array}$ & $\begin{array}{c}\text { Ventana SP263 } \\
\text { (complementary) }\end{array}$ & $\begin{array}{l}\text { Weight-based dosing } \\
(10 \mathrm{mg} / \mathrm{kg}) \text { or fixed dosing } \\
\text { (1500 mg) (not } \\
\text { FDA-approved) }\end{array}$ & 2017 & AstraZeneca \\
\hline
\end{tabular}




\subsubsection{Anti-PD-1/PD-L1}

The first two anti-PD-1 CPIs licensed were nivolumab and pembrolizumab, based on their anti-tumor activity in phase I studies [34-36]. Pembrolizumab is an IgG4 human antibody; these antibodies have a low affinity for $\mathrm{C} 1 \mathrm{q}$ and $\mathrm{Fc}$ receptors compared to other IgG molecules, making them a good antibody choice for immunotherapy, with the lowest chance of host immunity stimulation [37]. Most IgG4 antibodies are capable of a process called Fab arm exchange, in which half-molecules (a heavy chain and attached light chain) can be exchanged between IgG4 molecules [38]; pembrolizumab has a hinge region containing a S288P mutation, which prevents Fab arm exchange due to a conformational change $[39,40]$. The structure of nivolumab is very similar; it is an IgG4 antibody which differs from pembrolizumab only in the variable region of epitope binding-pembrolizumab binds to the $\mathrm{C}^{\prime} \mathrm{D}$ loop and nivolumab binds to the N-terminal loop on the PD-1 molecule [41].

Atezolizumab was the first anti-PD-L1 antibody licensed in the US. Atezolizumab and the other licensed anti-PD-L1 antibodies avelumab and durvalumab are IgG1 antibodies, which bind to the front beta-sheet of PD-L1. The heavy chain and light chain regions of these antibodies are involved in binding, with varying buried surface areas on each molecule which may affect their binding affinities $[42,43]$. These three antibodies have been noted to use all three complementarity determining regions from their heavy chains and two from the light chains [43,44].

After ipilimumab was licensed for the treatment of metastatic melanoma in 2011, the anti-PD-1 and anti-PD-L1 CPIs were subsequently approved for the treatment of many other cancer types, in the metastatic, adjuvant and neo-adjuvant settings. Initial approvals were for refractory/advanced melanoma and non-small cell lung cancer (NSCLC) for the anti-PD-1 CPIs, with subsequent licensing for their use in head and neck cancers, renal cell carcinoma, Hodgkin lymphoma and urothelial carcinomas [45]. Interestingly, the anti-PD-1 antibody pembrolizumab was the first oncologic therapy to be approved for use on the basis of a genetic alteration, with FDA approval granted in 2017 for its use in any tumor demonstrating microsatellite instability (MSI) [46]. The anti-PD-L1 antibodies are used in urothelial, kidney, lung and Merkel cell carcinoma, with many further studies ongoing. The presence of high tumor mutational burden (TMB) (the number of somatic tumor mutations per megabase of sequenced DNA) may identify tumors that are more likely to respond to CPI, such as those tumors that are microsatellite-unstable; however, to date, high TMB is not used to select therapy for patients [47]. Interestingly, responses to CPIs can be durable, with subsets of patients achieving long-lasting complete responses in some disease types, although, for many others, immune escape mechanisms develop, allowing tumors to evade the response primed by CPIs [48]. These treatments generally have a high tolerability, although the main toxicities, which are immune-related inflammatory effects, may be serious in a subset of patients.

\subsubsection{Binding Affinities and Pharmacokinetics}

Nivolumab has a binding affinity to the PD-1 protein of $3.06 \mathrm{nM}$, while pembrolizumab has an even higher affinity, with a dissociation constant of $27 \mathrm{pM}$, possibly due to its extensive binding sites to PD-1, which include hydrogen bonds, specifically water-mediated hydrogen bonds, and salt bridges [41,49,50]. Interestingly, pembrolizumab has a much lower affinity for mouse PD-1, which may be explained by specific amino acid substitutions ( $\mathrm{Asp}^{85}$ to $\mathrm{Gly}^{85}$ ) which, when mutated in human PD-1, abolish pembrolizumab binding. Atezolizumab has a high binding affinity of $0.4 \mathrm{nM}$, utilizing specific hot-spot residues on the protein binding surface [42,51], while avelumab and durvalumab have dissociation constants of $42.1 \mathrm{pM}$ [43] and $667 \mathrm{pM}$ [52], respectively.

Studies have shown moderate inter-individual variability (IIV) in pharmacokinetics of CPIs. Ipilimumab has stable clearance over dose ranges from 0.3 to $10 \mathrm{mg} / \mathrm{kg}$, with a half-life of 14.7 days and IIV largely influenced by body weight and baseline LDH value, while age, gender, renal and hepatic function do not affect clearance [53]. The steady state trough concentration of ipilimumab is a predictor of response, with higher trough concentrations (in patients receiving higher doses) resulting in improved complete response rates and higher overall survival (OS), but also in increased 
rates of irAEs [54,55]. Both the anti-PD-1 antibodies nivolumab and pembrolizumab have linear clearance over dose ranges of $0.1-20 \mathrm{mg} / \mathrm{kg}$ and $1-10 \mathrm{mg} / \mathrm{kg}$ respectively, with both demonstrating a time-dependent decline in clearance rates, although the decline did not appear to impact clinical outcomes [56-58]. For the anti-PD-L1 antibodies atezolizumab, avelumab and durvalumab, linear clearance is seen again over wide ranges of doses. For atezolizumab, which is usually used at a fixed dose of $1200 \mathrm{mg}$, clearance was stable at doses between 1-20 mg/kg and rates were affected by body weight and serum albumin [59]. Avelumab has a similar linear clearance, but interestingly, time-dependent clearance changes differed between tumor types, with Merkel cell carcinoma and head and neck squamous cell carcinoma patients having clearance declines of $24-32 \%$, while all other tumor types had minimal decline in clearance over time [60]. Durvalumab had linear clearance at doses higher than $3 \mathrm{mg} / \mathrm{kg}$, with numerous factors influencing clearance including albumin, body weight, cancer type and gender [61]. Interestingly, a factor that influences clearance in all three anti-PD-L1 antibodies is the development of anti-drug antibodies, which develop in 31.7\%, 4.16\% and 3.1\% respectively for atezolizumab, avelumab and durvalumab, but are unlikely to be clinically relevant as they did not affect clearance to a meaningful degree.

The antitumor effect of pembrolizumab is driven by the reactivation of adaptive immune response by inhibiting PD-1 expressed on T-cells. Once the PD-1 on T-cells are fully saturated by pembrolizumab, the shape of the exposure-response relationship within the dose range of $2-10 \mathrm{mg} / \mathrm{kg}$ or $200 \mathrm{mg}$ (exposure at $2 \mathrm{mg} / \mathrm{kg}$ every three weeks is similar to exposure at $200 \mathrm{mg}$ every three weeks) is flat, as demonstrated in multiple indications [62]. Available pharmacokinetics (PK) results in participants with various indications (melanoma, NSCLC, HNSCC, and MSI-H) supporting a lack of meaningful difference in PK among tumor types. Therefore, the selection of the $200 \mathrm{mg}$ every three weeks dosing for pembrolizumab was supported as an appropriate dose for multiple tumor types.

Similarly, nivolumab, dosed at a fixed dose of either $240 \mathrm{mg}$ every two weeks or 480 mg every four weeks results in a similar time-averaged steady state exposure and safety as $3 \mathrm{mg} / \mathrm{kg}$ every two weeks across multiple tumor types in numerous clinical trials, and is approved at a fixed dosing for most indications [63-65]. Peripheral PD-1 receptor occupancy is saturated at doses $\geq 0.3 \mathrm{mg} / \mathrm{kg}$ after eight weeks treatment, again supporting minimizing the doses administered, although the degree of intra-tumoral receptor occupancy is not yet known [66]. Some regulatory authorities have suggested weight-based dosing for patients less than $80 \mathrm{~kg}$ and fixed dosing above, to avoid unnecessarily high doses for lower-weight patients [67]. Avelumab is currently approved at a weight-based dosing of $10 \mathrm{mg} / \mathrm{kg}$, but simulations suggested that similar risk/benefit profiles would result from fixed dosing at $800 \mathrm{mg}$, leading to FDA approval of this fixed dose [68]. Issues with cost and drug wastage are also improved with flat dosing [69]; these results are leading to a move towards fixed dosing in many CPI indications and trials, as evidence from the majority of CPIs demonstrates that exposure, efficacy and safety are similar to weight-based dosing.

\subsubsection{Immune-Related Adverse Events}

A full discussion of the irAEs associated with CPIs is beyond the scope of this review, but, briefly, these side effects are due to off-target activation or dysregulation of the immune system, which can affect any body organ or system. Common organs affected include the bowel, causing colitis, which can be severe, the lungs, causing pneumonitis, the thyroid gland, which can cause both overproduction or underproduction of the thyroid hormone, the adrenal or pituitary glands, the liver and the skin [70]. There appear to be some patterns to the frequency of irAEs with various CPIs, with colitis and hypophysitis more common with the anti-CTLA-4 antibodies and pneumonitis and hypothyroidism more frequently seen with anti-PD-1 therapies [71]. Deaths from irAEs are rare but do occur, with the most common causes being severe colitis and pneumonitis [71]. Rates of grade 3-4 irAEs increase with combination treatment compared with single agent treatment; for example, treatment of metastatic melanoma with ipilimumab and nivolumab resulted in 59\% grade 3-4 AEs, compared with $21 \%$ for nivolumab alone and $28 \%$ for ipilimumab alone [72]. The management of irAEs includes use of steroids 
for less severe cases, and immunosuppression for more severe cases, using agents such as infliximab and mycophenolate [73].

\section{Optimization of Checkpoint Inhibitors}

While CPIs are part of standard of care in multiple tumor types, efforts to optimize these antibodies to improve their efficacy and safety are currently underway.

\subsection{Non-Fucosylated Antibodies}

Non-fucosylated antibodies have been modified so that the glycans in the Fc binding portion of the antibody are not fucose-bound. This modification enhances the antibody-dependent cell-mediated cytotoxicity (ADCC) via the enrichment of Fc-gamma-receptor-expressing effector cells and depletion of T-regulatory cells [74-77]. A non-fucosylated variant of ipilimumab has been constructed, and, in mice, demonstrated increased anti-tumor activity, peripheral T-cell activation and T-reg depletion compared with standard ipilimumab, and also enhanced T-cell-mediated vaccine responses in macaques $[76,78]$. A modified molecule, similar to atezolizumab but with reduced core fucosylation, demonstrated increased binding to Fc-gamma-receptor-IIIa and enhanced ADCC against PD-L1-expressing tumor cells in a cell-line model [79]. Knockout of the fucosyltransferase gene FUT8 or the pharmacologic inhibition of this gene, which decreased fucosylation, resulted in decreased PD-1 expression and increased T-cell activation in mice, again supporting this as a potential mechanism to enhance the activity of checkpoint inhibitors [80]. Phase I trials of non-fucosylated ipilimumab are enrolling.

\subsection{Pro-Drug Formulations}

Prodrug formulations of antibodies utilize a masking peptide that binds to the antigen-binding site of the CPI which reduces systemic activity. When the antibody reaches the tumor site, proteases cleave the masking peptide and the antibody becomes fully functional, allowing tumor-targeted activity and theoretically reducing off-target systemic adverse effects. Prodrug versions of ipilimumab have been developed and demonstrate equivalent anti-tumor and immune activity and reduced lymphohistiocytic inflammation in the gastrointestinal tract and kidneys compared with standard ipilimumab [76,78]. The result is an improved safety profile. Probody ${ }^{\mathrm{TM}}$ therapeutics are protease-activated antibodies which have shown pre-clinical efficacy targeting PD-L1 with minimal systemic auto-immunity [81,82]; the Probody drug CX-072 is now in phase I/II clinical trial for solid tumors and lymphoma [NCT03013491].

\subsection{Bispecific Antibodies}

Another method to optimize CPIs is to fuse them to another antibody which can then simultaneously bind another target molecule. These molecules then have the extracellular domains of two separate antibodies, both of which can bind to their respective ligands and retain their signaling activity. An example of this type of protein is the PD1-Fc-OX40L molecule, which, on testing, retained its high affinity binding for both PD-L1/L2 and OX40, caused T-cell activation and also demonstrated an improved anti-tumor immune response compared with single antibody treatment or the combination of the two separate PD-1 and OX40 antibodies [83]. A bispecific antibody to CTLA-4 and OX40 has also been effective in pre-clinical models, reducing tumor growth and enhancing response to PD-1 targeted therapy, and is now in phase I clinical trials [NCT03782467] [84]. The RANK/RANKL pathway is usually associated with bone homeostasis and is targeted using bone-protective agents, such as denosumab in patients with metastatic bony lesions and with osteoporosis [85]. However, this pathway is also involved in the tumor-associated immune response, with increased RANKL expression seen in tumor-infiltrating T-cells and RANK expression on dendritic cells and immunosuppressive M2 macrophages [86]. While trials are underway combining CPIs with denosumab, bispecific antibodies targeting the PD-1/PD-L1 and RANK/RANKL pathways have been developed, and show significant anti-tumor activity in mouse models, in particular those of colon and lung cancer [87]. This activity 
was dependent on CD8+ T cells and IFN-y, and could be increased further by combining the bispecific antibody with an anti-CTLA4 antibody.

Bispecific antibodies have already entered early phase clinical trials. A fusion protein consisting of an anti-PD-L1 antibody fused to the extracellular domain of TGF- $\beta$ receptor II, M7824, showed excellent pre-clinical activity, suppressing metastases, inducing long-term anti-tumor immunity and improving OS in mouse models of breast and colon cancer, both as a single agent and in combination with a therapeutic cancer vaccine [88,89]. It is currently in phase I/II trials in many cancer types including breast, prostate, lung, biliary tract and colorectal, with an early biliary tract cancer trial showing an overall response rate of 27\% [PMC6421177, PMC6421170]. Another bispecific antibody, MGD013, which targets PD-L1 and LAG-3, another CPI, has shown pre-clinical activity and is in phase I trials in solid tumors [NCT03219268] [90,91]. Issues that arise with bispecific antibodies include the potential for increased immunogenicity and therefore more adverse events, as well as difficulties with safety assessments in animal models. There are many other bispecific antibodies in pre-clinical development, combining immune checkpoint blockade with other tumor-specific protein binding.

\section{New Agents Targeting Immune Checkpoints}

\subsection{Small Molecule Checkpoint Inhibitors}

While there has been considerable progress in the development of antibodies targeting the PD-1/PD-L1 pathway, interest has been growing in attempts to block this axis using small molecules. The purported benefits of using small molecules rather than antibodies include potentially better oral bioavailability, fewer immune-related adverse events, improved tumor penetration and a lower production cost. The initial molecules shown to inhibit this pathway were sulfamonomethoxine and sulfamethizole, which could rescue PD-1-mediated inhibition of IFN-g production, a process which was dependent on PD-L2 [92]. Substituting particular rings in the structure of the sulfamethizole compound, such as a phenyl ring instead of a pyridyl ring, improved the efficacy of the compound in restoring IFN-yexpression. While, ultimately, research into these compounds was not continued, they provided proof of concept for the small molecule inhibition of the PD-1/PD-L1 pathway.

Several other small molecule compounds that inhibit PD-L1 have been patented [93]. These molecules have been shown to bind directly to each dimer of PD-L1 and can dissociate the PD-1/PD-L1 complex, and certain "hot spots" on the PD-L1 molecule, which are targetable by small molecules, have been identified using in vitro studies of these compounds [94,95]. However, one of the major problems with small molecule inhibitors to date has been their large molecular weight, which impairs adequate absorption and distribution in the human body.

The only small molecule currently in human clinical trials is a molecule called Ca-170, which inhibits both the PD-L1 pathway and the V-domain Ig suppressor of the T-cell activation (VISTA) pathway. Pre-clinical work has demonstrated that in mice, this molecule can inhibit tumor growth, enhance peripheral T cell activation and increase activation of tumor-infiltrating CD8+ T-cells $[96,97]$. Oral bioavailability in mice was $40 \%$, but in monkeys was $<10 \%$, again raising the issue of oral administration of these compounds. Ca-170 is in phase 1 clinical trials in patients with advanced solid tumors and lymphoma, and also in phase II trials, with a clinical benefit rate of $59.5 \%$ reported, and higher response rates seen at lower doses [98]. Interestingly, a recent study examining the mechanism of binding of Ca-170 has shown that there is no direct binding between the compound and the PD-L1 molecule, suggesting there may be an alternative mechanism of action [99]. To date, the majority of small molecule inhibitors of PD-L1 do not appear to be ready for widespread clinical usage and further pre-clinical work is needed to optimize their formulation and use.

\subsection{Peptide Checkpoint Inhibitors}

As described above, the crystal structure of the PD-1 and PD-L1 molecules and the mechanism by which they bind has been clearly defined, and, therefore, interest has grown in designing a peptide 
inhibitor that could bind to one of these binding sites. With this data, the first peptide antagonist, (D)PPA-1, was described in 2015, and designed using a mirror-image phage display method, binding to PD-L1 and blocking the PD-1/PD-L1 interaction and decreasing tumor growth in vivo [100]. Replacing the L-amino acids with D-amino acids can improve the stability and oral bioavailability of these drugs. Another more recently developed peptide, PL120131, was designed to interact with the PD-1 molecule, based on the interacting residues on PD-L1 from the amino acid glycine at position 120 to asparagine at position 131 [101]. PL120131 was shown to act as a competitive inhibitor of PD-L1 by associating with the binding groove on PD-1, and to reverse the apoptotic signal induced by soluble PD-L1 in Jurkat cells and primary lymphocytes. Another class of peptides are the macrocyclic peptides, which bind to the PD-1-binding site on the PD-L1 molecule, and can restore T-cell function in vitro [102].

To date, none of the peptide inhibitors of the PD-1/PD-L1 pathway have been used in human trials. The peptide molecule TPP-1 has a high affinity for human PD-L1, and, in a mouse model, could decrease tumor growth by $56 \%$ compared with control peptide-treated mice, by re-activating $\mathrm{T}$ cells through blocking the PD-1/PD-L1 interaction [103]. A compound called UNP-12 demonstrated a 44\% reduction in tumor growth in mice [104,105]. More recently, NP-12, which also inhibits the PD-1/PD-L1 interaction and can inhibit tumor growth and metastases in colon and melanoma mouse models, demonstrated improved efficacy when combined with tumor vaccination or cyclophosphamide [106]. The peptide inhibitors are still in early phases of development but may provide an alternative method through which to inhibit immune checkpoints.

\section{Conclusions}

CPIs have changed the landscape of cancer treatment in recent years, with a small proportion of patients with a variety of tumors experiencing deep and durable responses. Understanding the pharmacokinetics of many CPIs has led to a switch from weight-based to fixed dosing, which is likely to continue as more studies of the efficacy and PK of fixed dosing are completed. IrAEs and heterogeneity in responses has led to efforts to optimize existing CPIs and to develop new methods by which to inhibit checkpoint molecules. Understanding the structure of CPIs and their ligands can help in the further enhancement of these therapeutic agents.

Funding: This research received no external funding.

Conflicts of Interest: The authors declare no conflict of interest

\section{Abbreviations}

Abb.
A-2
ADCC
CPI
CTLA-4
IgG
IIV
IL-12
irAE
nM
OS
PD-1
PD-L1
PD-L2
pM
RANK
RANKL
T-reg

Full Name

angstrom-2

antibody-dependent cell-mediated cytotoxicity checkpoint inhibitors

cytotoxic T-lymphocyte associated protein- 4

immunoglobulin G

interindividual variability

interleukin-12

immune-related adverse event

nanomolar

overall survival

programmed cell death protein-1

programmed cell death protein ligand-1

programmed cell death protein ligand-2

picomolar

Receptor activator of nuclear factor kappa-B

Receptor activator of nuclear factor kappa-B ligand

T-regulatory 


\section{References}

1. Brunet, J.F.; Denizot, F.; Luciani, M.F.; Roux-Dosseto, M.; Suzan, M.; Mattei, M.-G.; Golstein, P. A new member of the immunoglobulin superfamily-Ctla-4. Nature 1987, 328, 267-270. [CrossRef] [PubMed]

2. Lindsten, T.; Lee, K.P.; Harris, E.S.; Petryniak, B.; Craighead, N.; Reynolds, P.J.; Lombard, D.B.; Freeman, G.J.; Nadler, L.M.; Gray, G.S.; et al. Characterization of CTLA-4 structure and expression on human T cells. J. Immunol. 1993, 151, 3489-3499. [PubMed]

3. Tivol, E.A.; Borriello, F.; Schweitzer, A.N.; Lynch, W.P.; Bluestone, J.A.; Sharpe, A.H. Loss of CTLA-4 leads to massive lymphoproliferation and fatal multiorgan tissue destruction, revealing a critical negative regulatory role of CTLA-4. Immunity 1995, 3, 541-547. [CrossRef]

4. Ishida, Y.; Agata, Y.; Shibahara, K.; Honjo, T. Induced expression of PD-1, a novel member of the immunoglobulin gene superfamily, upon programmed cell death. EMBO J. 1992, 11, 3887-3895. [CrossRef]

5. Nishimura, H.; Nose, M.; Hiai, H.; Minato, N.; Honjo, T. Development of lupus-like autoimmune diseases by disruption of the PD-1 gene encoding an ITIM motif-carrying immunoreceptor. Immunity 1999, 11, 141-151. [CrossRef]

6. Nishimura, H.; Okazaki, T.; Tanaka, Y.; Nakatani, K.; Hara, M.; Matsumori, A.; Sasayama, S.; Mizoguchi, A.; Hiai, H.; Minato, N.; et al. Autoimmune dilated cardiomyopathy in PD-1 receptor-deficient mice. Science 2001, 291, 319-322. [CrossRef]

7. Zhong, X.; Bai, C.; Gao, W.; Strom, T.B.; Rothstein, T.L. Suppression of expression and function of negative immune regulator PD-1 by certain pattern recognition and cytokine receptor signals associated with immune system danger. Int. Immunol. 2004, 16, 1181-1188. [CrossRef]

8. Zak, K.M.; Grudnik, P.; Magiera, K.; Domling, A.; Dubin, G.; Holak, T.A. Structural Biology of the Immune Checkpoint Receptor PD-1 and Its Ligands PD-L1/PD-L2. Structure 2017, 25, 1163-1174. [CrossRef]

9. Guzik, K.; Zak, K.M.; Grudnik, P.; Magiera, K.; Musielak, B.; Törner, R.; Skalniak, L.; Dömling, A.; Dubin, G.; Holak, T.A. Small-Molecule Inhibitors of the Programmed Cell Death-1/Programmed Death-Ligand 1 (PD-1/PD-L1) Interaction via Transiently Induced Protein States and Dimerization of PD-L1. J. Med. Chem. 2017, 60, 5857-5867. [CrossRef]

10. Zak, K.M.; Kitel, R.; Przetocka, S.; Golik, P.; Guzik, K.; Musielak, B.; Dömling, A.; Dubin, G.; Holak, T.A. Structure of the Complex of Human Programmed Death 1, PD-1, and Its Ligand PD-L1. Structure 2015, 23, 2341-2348. [CrossRef]

11. Lazar-Molnar, E.; Yan, Q.; Cao, E.; Ramagopal, U.; Nathenson, S.G.; Almo, S.C. Crystal structure of the complex between programmed death-1 (PD-1) and its ligand PD-L2. Proc. Natl. Acad. Sci. USA 2008, 105, 10483-10488. [CrossRef] [PubMed]

12. Lin, D.Y.; Tanaka, Y.; Iwasaki, M.; Gittis, A.G.; Su, H.P.; Mikami, B.; Okazaki, T.; Honjo, T.; Minato, N.; Garboczi, D.N. The PD-1/PD-L1 complex resembles the antigen-binding Fv domains of antibodies and T cell receptors. Proc. Natl. Acad. Sci. USA 2008, 105, 3011-3016. [CrossRef] [PubMed]

13. Leach, D.R.; Krummel, M.F.; Allison, J.P. Enhancement of antitumor immunity by CTLA-4 blockade. Science 1996, 271, 1734-1736. [CrossRef] [PubMed]

14. Watanabe, T.; Bertoletti, A.; Tanoto, T.A. PD-1/PD-L1 pathway and T-cell exhaustion in chronic hepatitis virus infection. J. Viral Hepat. 2010, 17, 453-458. [CrossRef] [PubMed]

15. Kinter, A.L.; Godbout, E.J.; McNally, J.P.; Sereti, I.; Roby, G.A.; O'Shea, M.A.; Fauci, A.S. The common gamma-chain cytokines IL-2, IL-7, IL-15, and IL-21 induce the expression of programmed death-1 and its ligands. J. Immunol. 2008, 181, 6738-6746. [CrossRef] [PubMed]

16. Nam, S.; Lee, A.; Lim, J.; Lim, J.S. Analysis of the Expression and Regulation of PD-1 Protein on the Surface of Myeloid-Derived Suppressor Cells (MDSCs). Biomol. Ther. 2019, 27, 63-70. [CrossRef] [PubMed]

17. Guram, K.; Kim, S.S.; Wu, V.; Sanders, P.D.; Patel, S.; Schoenberger, S.P.; Cohen, E.E.W.; Chen, S.Y.; Sharabi, A.B. A Threshold Model for T-Cell Activation in the Era of Checkpoint Blockade Immunotherapy. Front. Immunol. 2019, 10, 491. [CrossRef]

18. Sanchez-Paulete, A.R.; Teijeira, A.; Cueto, F.J.; Garasa, S.; Pérez-Gracia, J.L.; Sánchez-Arráez, A.; Sancho, D.; Melero, I. Antigen cross-presentation and T-cell cross-priming in cancer immunology and immunotherapy. Ann. Oncol. 2017, 28, xii44-xii55. [CrossRef] 
19. Parry, R.V.; Chemnitz, J.M.; Frauwirth, K.A.; Lanfranco, A.R.; Braunstein, I.; Kobayashi, S.V.; Linsley, P.S.; Thompson, C.B.; Riley, J.L. LCTLA-4 and PD-1 receptors inhibit T-cell activation by distinct mechanisms. Mol. Cell. Biol. 2005, 25, 9543-9553. [CrossRef]

20. Taube, J.M.; Anders, R.A.; Young, G.D.; Xu, H.; Sharma, R.; McMiller, T.L.; Chen, S.; Klein, A.P.; Pardoll, D.M.; Topalian, S.L.; et al. Colocalization of inflammatory response with B7-h1 expression in human melanocytic lesions supports an adaptive resistance mechanism of immune escape. Sci. Transl. Med. 2012, 4, $127 \mathrm{ra37.}$ [CrossRef]

21. Sabatier, R.; Finetti, P.; Mamessier, E.; Adelaide, J.; Chaffanet, M.; Ali, H.R.; Viens, P.; Caldas, C.; Birnbaum, D.; Bertucci, F. Prognostic and predictive value of PDL1 expression in breast cancer. Oncotarget 2015, 6, 5449-5464. [CrossRef] [PubMed]

22. Rahn, S.; Kruger, S.; Mennrich, R.; Goebel, L.; Wesch, D.; Oberg, H.H.; Vogel, I.; Ebsen, M.; Röcken, C.; Helm, O.; et al. POLE Score: A comprehensive profiling of programmed death 1 ligand 1 expression in pancreatic ductal adenocarcinoma. Oncotarget 2019, 10, 1572-1588. [CrossRef] [PubMed]

23. Velcheti, V.; Schalper, K.A.; Carvajal, D.E.; Anagnostou, V.K.; Syrigos, K.N.; Sznol, M.; Herbst, R.S.; Gettinger, S.N.; Chen, L.; Rimm, D.L. Programmed death ligand-1 expression in non-small cell lung cancer. Lab. Invest. 2014, 94, 107-116. [CrossRef] [PubMed]

24. Muenst, S.; Schaerli, A.R.; Gao, F.; Däster, S.; Trella, E.; Droeser, R.A.; Muraro, M.G.; Zajac, P.; Zanetti, R.; Gillanders, W.E.; et al. Expression of programmed death ligand 1 (PD-L1) is associated with poor prognosis in human breast cancer. Breast Cancer Res. Treat. 2014, 146, 15-24. [CrossRef]

25. Daud, A.I.; Wolchok, J.D.; Robert, C.; Hwu, W.J.; Weber, J.S.; Ribas, A.; Hodi, F.S.; Joshua, A.M.; Kefford, R.; Hersey, P.; et al. Programmed Death-Ligand 1 Expression and Response to the Anti-Programmed Death 1 Antibody Pembrolizumab in Melanoma. J. Clin. Oncol. 2016, 34, 4102-4109. [CrossRef]

26. Macek Jilkova, Z.; Aspord, C.; Decaens, T. Predictive Factors for Response to PD-1/PD-L1 Checkpoint Inhibition in the Field of Hepatocellular Carcinoma: Current Status and Challenges. Cancers 2019, 11, 1554. [CrossRef]

27. Munari, E.; Zamboni, G.; Marconi, M.; Sommaggio, M.; Brunelli, M.; Martignoni, G.; Terzi, A. PD-L1 expression heterogeneity in non-small cell lung cancer: Evaluation of small biopsies reliability. Oncotarget 2017, 8, 90123-90131. [CrossRef]

28. Munari, E.; Zamboni, G.; Lunardi, G.; Sommaggio, M.; Brunelli, M.; Martignoni, G.; Netto, G.J.; Moretta, F.; Mingari, M.C.; Salgarello, M.; et al. PD-L1 expression comparison between primary and relapsed non-small cell lung carcinoma using whole sections and clone SP263. Oncotarget 2018, 9, 30465-30471. [CrossRef]

29. Callea, M.; Albiges, L.; Gupta, M.; Cheng, S.C.; Genega, E.M.; Fay, A.P.; Song, J.; Carvo, I.; Bhatt, R.S.; Atkins, M.B.; et al. Differential expression of PD-L1 between primary and metastatic sites in clear-cell renal cell carcinoma. Cancer Immunol. Res. 2015, 3, 1158-1164. [CrossRef]

30. Madore, J.; Vilain, R.E.; Menzies, A.M.; Kakavand, H.; Wilmott, J.S.; Hyman, J.; Yearley, J.H.; Kefford, R.F.; Thompson, J.F.; Long, G.V.; et al. PD-L1 expression in melanoma shows marked heterogeneity within and between patients: Implications for anti-PD-1/PD-L1 clinical trials. Pigment Cell Melanoma Res. 2015, 28, 245-253. [CrossRef]

31. Ramagopal, U.A.; Liu, W.; Garrett-Thomson, S.C.; Bonanno, J.B.; Yan, Q.; Srinivasan, M.; Wong, S.C.; Bell, A.; Mankikar, S.; Rangan, V.S.; et al. Structural basis for cancer immunotherapy by the first-in-class checkpoint inhibitor ipilimumab. Proc. Natl. Acad. Sci. USA 2017, 114, E4223-E4232. [CrossRef] [PubMed]

32. Strome, S.E.; Sausville, E.A.; Mann, D. A mechanistic perspective of monoclonal antibodies in cancer therapy beyond target-related effects. Oncologist 2007, 12, 1084-1095. [CrossRef] [PubMed]

33. Camacho, L.H.; Antonia, S.; Sosman, J.; Kirkwood, J.M.; Gajewski, T.F.; Redman, B.; Pavlov, D.; Bulanhagui, C.; Bozon, V.A.; Gomez-Navarro, J.; et al. Phase I/II trial of tremelimumab in patients with metastatic melanoma. J. Clin. Oncol. 2009, 27, 1075-1081. [CrossRef] [PubMed]

34. Brahmer, J.R.; Drake, C.G.; Wollner, I.; Powderly, J.D.; Picus, J.; Sharfman, W.H.; Stankevich, E.; Pons, A.; Salay, T.M.; McMiller, T.L.; et al. Phase I study of single-agent anti-programmed death-1 (MDX-1106) in refractory solid tumors: Safety, clinical activity, pharmacodynamics, and immunologic correlates. J. Clin. Oncol. 2010, 28, 3167-3175. [CrossRef] [PubMed]

35. Hamid, O.; Robert, C.; Daud, A.; Hodi, F.S.; Hwu, W.J.; Kefford, R.; Wolchok, J.D.; Hersey, P.; Joseph, R.W.; Weber, J.S.; et al. Safety and tumor responses with lambrolizumab (anti-PD-1) in melanoma. N. Engl. J. Med. 2013, 369, 134-144. [CrossRef] 
36. Topalian, S.L.; Hodi, F.S.; Brahmer, J.R.; Gettinger, S.N.; Smith, D.C.; McDermott, D.F.; Powderly, J.D.; Carvajal, R.D.; Sosman, J.A.; Atkins, M.B.; et al. Safety, activity, and immune correlates of anti-PD-1 antibody in cancer. N. Engl. J. Med. 2012, 366, 2443-2454. [CrossRef]

37. Jefferis, R.; Lund, J. Interaction sites on human IgG-Fc for FcgammaR: Current models. Immunol. Lett. 2002, 82, 57-65. [CrossRef]

38. Van der Neut Kolfschoten, M.; Schuurman, J.; Losen, M.; Bleeker, W.K.; Martínez-Martínez, P.; Vermeulen, E.; De Baets, M.H. Anti-inflammatory activity of human IgG4 antibodies by dynamic Fab arm exchange. Science 2007, 317, 1554-1557. [CrossRef]

39. Angal, S.; King, D.J.; Bodmer, M.W.; Turner, A.; Lawson, A.D.; Roberts, G.; Pedley, B.; Adair, J.R. A single amino acid substitution abolishes the heterogeneity of chimeric mouse/human (IgG4) antibody. Mol. Immunol. 1993, 30, 105-108. [CrossRef]

40. Scapin, G.; Yang, X.; Prosise, W.W.; McCoy, M.; Reichert, P.; Johnston, J.M.; Kashi, R.S.; Strickland, C. Structure of full-length human anti-PD1 therapeutic IgG4 antibody pembrolizumab. Nat. Struct. Mol. Biol. 2015, 22, 953-958. [CrossRef]

41. Tan, S.; Zhang, H.; Chai, Y.; Song, H.; Tong, Z.; Wang, Q.; Qi, J.; Wong, G.; Zhu, X.; Liu, W.J.; et al. An unexpected N-terminal loop in PD-1 dominates binding by nivolumab. Nat. Commun. 2017, 8, 14369. [CrossRef] [PubMed]

42. Zhang, F.; Qi, X.; Wang, X.; Wei, D.; Wu, J.; Feng, L.; Cai, H.; Wang, Y.; Zeng, N.; Xu, T.; et al. Structural basis of the therapeutic anti-PD-L1 antibody atezolizumab. Oncotarget 2017, 8, 90215-90224. [CrossRef] [PubMed]

43. Liu, K.; Tan, S.; Chai, Y.; Chen, D.; Song, H.; Zhang, C.W.; Shi, Y.; Liu, J.; Tan, W.; Lyu, J.; et al. Structural basis of anti-PD-L1 monoclonal antibody avelumab for tumor therapy. Cell Res. 2017, 27, 151-153. [CrossRef] [PubMed]

44. Lee, H.T.; Lee, J.Y.; Lim, H.; Lee, S.H.; Moon, Y.J.; Pyo, H.J.; Ryu, S.E.; Shin, W.; Heo, Y.S. Molecular mechanism of PD-1/PD-L1 blockade via anti-PD-L1 antibodies atezolizumab and durvalumab. Sci. Rep. 2017, 7, 5532. [CrossRef]

45. Ribas, A.; Wolchok, J.D. Cancer immunotherapy using checkpoint blockade. Science 2018, 359, $1350-1355$. [CrossRef]

46. Le, D.T.; Durham, J.N.; Smith, K.N.; Wang, H.; Bartlett, B.R.; Aulakh, L.K.; Lu, S.; Kemberling, H.; Wilt, C.; Luber, B.S.; et al. Mismatch repair deficiency predicts response of solid tumors to PD-1 blockade. Science 2017, 357, 409-413. [CrossRef]

47. Klempner, S.J.; Fabrizio, D.; Bane, S.; Reinhart, M.; Peoples, T.; Ali, S.M.; Sokol, E.S.; Frampton, G.; Schrock, A.B.; Anhorn, R.; et al. Tumor mutational burden as a predictive biomarker for response to immune checkpoint inhibitors: A review of current evidence. Oncologist 2019. [CrossRef]

48. Sharma, P.; Hu-Lieskovan, S.; Wargo, J.A.; Ribas, A. Primary, adaptive, and acquired resistance to cancer immunotherapy. Cell 2017, 168, 707-723. [CrossRef]

49. Na, Z.; Yeo, S.P.; Bharath, S.R.; Bowler, M.W.; Balıkçı, E.; Wang, C.I.; Song, H. Structural basis for blocking PD-1-mediated immune suppression by therapeutic antibody pembrolizumab. Cell Res. 2017, 27, 147-150. [CrossRef]

50. Horita, S.; Nomura, Y.; Sato, Y.; Shimamura, T.; Iwata, S.; Nomura, N. High-resolution crystal structure of the therapeutic antibody pembrolizumab bound to the human PD-1. Sci. Rep. 2016, 6, 35297. [CrossRef]

51. Herbst, R.S.; Soria, J.C.; Kowanetz, M.; Fine, G.D.; Hamid, O.; Gordon, M.S.; Sosman, J.A.; McDermott, D.F.; Powderly, J.D.; Gettinger, S.N.; et al. Predictive correlates of response to the anti-PD-L1 antibody MPDL3280A in cancer patients. Nature 2014, 515, 563-567. [CrossRef] [PubMed]

52. Tan, S.; Liu, K.; Chai, Y.; Zhang, C.W.; Gao, S.; Gao, G.F.; Qi, J. Distinct PD-L1 binding characteristics of therapeutic monoclonal antibody durvalumab. Protein Cell 2018, 9, 135-139. [CrossRef] [PubMed]

53. Feng, Y.; Masson, E.; Dai, D.; Parker, S.M.; Berman, D.; Roy, A. Model-based clinical pharmacology profiling of ipilimumab in patients with advanced melanoma. Br. J. Clin. Pharmacol. 2014, 78, 106-117. [CrossRef] [PubMed]

54. Feng, Y.; Roy, A.; Masson, E.; Chen, T.T.; Humphrey, R.; Weber, J.S. Exposure-response relationships of the efficacy and safety of ipilimumab in patients with advanced melanoma. Clin. Cancer Res. 2013, 19, 3977-3986. [CrossRef] 
55. Bertrand, A.; Kostine, M.; Barnetche, T.; Truchetet, M.E.; Schaeverbeke, T. Immune related adverse events associated with anti-CTLA-4 antibodies: Systematic review and meta-analysis. BMC Med. 2015, $13,211$. [CrossRef] [PubMed]

56. Elassaiss-Schaap, J.; Rossenu, S.; Lindauer, A.; Kang, S.P.; de Greef, R.; Sachs, J.R.; de Alwis, D.P. Using model-based "learn and confirm" to reveal the pharmacokinetics-pharmacodynamics relationship of pembrolizumab in the KEYNOTE-001 trial. CPT Pharmacomet. Syst. Pharmacol. 2017, 6, 21-28. [CrossRef]

57. Bajaj, G.; Wang, X.; Agrawal, S.; Gupta, M.; Roy, A.; Feng, Y. Model-Based population pharmacokinetic analysis of nivolumab in patients with solid tumors. CPT Pharmacomet. Syst. Pharmacol. 2017, 6, 58-66. [CrossRef]

58. Li, H.; Yu, J.; Liu, C.; Liu, J.; Subramaniam, S.; Zhao, H.; Blumenthal, G.M.; Turner, D.C.; Li, C.; Ahamadi, M.; et al. Time dependent pharmacokinetics of pembrolizumab in patients with solid tumor and its correlation with best overall response. J. Pharmacokinet. Pharmacodyn. 2017, 44, 403-414. [CrossRef]

59. Stroh, M.; Winter, H.; Marchand, M.; Claret, L.; Eppler, S.; Ruppel, J.; Abidoye, O.; Teng, S.L.; Lin, W.T.; Dayog, S.; et al. Clinical pharmacokinetics and pharmacodynamics of atezolizumab in metastatic urothelial carcinoma. Clin. Pharmacol. Ther. 2017, 102, 305-312. [CrossRef]

60. Wilkins, J.J.; Brockhaus, B.; Dai, H.; Vugmeyster, Y.; White, J.T.; Brar, S.; Bello, C.L.; Neuteboom, B.; Wade, J.R.; Girard, P.; et al. Time-Varying clearance and impact of disease state on the pharmacokinetics of avelumab in merkel cell carcinoma and urothelial carcinoma. CPT Pharmacomet. Syst. Pharmacol. 2019, 8, 415-427. [CrossRef]

61. Baverel, P.G.; Dubois, V.F.S.; Jin, C.Y.; Zheng, Y.; Song, X.; Jin, X.; Mukhopadhyay, P.; Gupta, A.; Dennis, P.A.; Ben, Y.; et al. Population pharmacokinetics of durvalumab in cancer patients and association with longitudinal biomarkers of disease status. Clin. Pharmacol. Ther. 2018, 103, 631-642. [CrossRef] [PubMed]

62. Freshwater, T.; Kondic, A.; Ahamadi, M.; Li, C.H.; de Greef, R.; de Alwis, D.; Stone, J.A. Evaluation of dosing strategy for pembrolizumab for oncology indications. J. Immunother. Cancer 2017, 5, 43. [CrossRef] [PubMed]

63. Long, G.V.; Tykodi, S.S.; Schneider, J.G.; Garbe, C.; Gravis, G.; Rashford, M.; Agrawal, S.; Grigoryeva, E.; Bello, A.; Roy, A.; et al. Assessment of nivolumab exposure and clinical safety of $480 \mathrm{mg}$ every 4 weeks flat-dosing schedule in patients with cancer. Ann. Oncol. 2018, 29, 2208-2213. [CrossRef] [PubMed]

64. Zhao, X.; Suryawanshi, S.; Hruska, M.; Feng, Y.; Wang, X.; Shen, J.; Vezina, H.E.; McHenry, M.B.; Waxman, I.M.; Achanta, A.; et al. Assessment of nivolumab benefit-risk profile of a 240-mg flat dose relative to a 3-mg/kg dosing regimen in patients with advanced tumors. Ann. Oncol. 2017, 28, 2002-2008. [CrossRef]

65. Bi, Y.; Liu, J.; Furmanski, B.; Zhao, H.; Yu, J.; Osgood, C.; Ward, A.; Keegan, P.; Booth, B.P.; Rahman, A.; et al. Model-informed drug development approach supporting approval of the 4-week (Q4W) dosing schedule for nivolumab (Opdivo) across multiple indications: A regulatory perspective. Ann. Oncol. 2019, 30, 644-651. [CrossRef]

66. Agrawal, S.; Feng, Y.; Roy, A.; Kollia, G.; Lestini, B. Nivolumab dose selection: Challenges, opportunities, and lessons learned for cancer immunotherapy. J. Immunother. Cancer 2016, 4. [CrossRef]

67. De Lemos, M.L.; Kung, C.; Waignein, S. Efficacy of nivolumab four-weekly dosing schedule based on body weight. J. Oncol. Pharm. Pract. 2019, 25, 961-963. [CrossRef]

68. Novakovic, A.M.; Wilkins, J.J.; Dai, H.; Wade, J.R.; Neuteboom, B.; Brar, S.; Bello, C.L.; Girard, P.; Khandelwal, A. Changing body weight-based dosing to a flat dose for avelumab in metastatic Merkel cell and advanced urothelial carcinoma. Clin. Pharmacol. Ther. 2019. [CrossRef]

69. Ogungbenro, K.; Patel, A.; Duncombe, R.; Nuttall, R.; Clark, J.; Lorigan, P. Dose rationalization of pembrolizumab and nivolumab using pharmacokinetic modeling and simulation and cost analysis. Clin. Pharmacol. Ther. 2018, 103, 582-590. [CrossRef]

70. Fessas, P.; Possamai, L.A.; Clark, J.; Daniels, E.; Gudd, C.; Mullish, B.H.; Alexander, J.L.; Pinato, D.J. Immunotoxicity from checkpoint inhibitor therapy: Clinical features and underlying mechanisms. Immunology 2019. [CrossRef]

71. Khoja, L.; Day, D.; Wei-Wu Chen, T.; Siu, L.L.; Hansen, A.R. Tumour-and class-specific patterns of immune-related adverse events of immune checkpoint inhibitors: A systematic review. Ann. Oncol. 2017, 28, 2377-2385. [CrossRef] [PubMed]

72. Wolchok, J.D.; Chiarion-Sileni, V.; Gonzalez, R.; Rutkowski, P.; Grob, J.J.; Cowey, C.L.; Lao, C.D.; Wagstaff, J.; Schadendorf, D.; Ferrucci, P.F.; et al. Overall Survival with Combined Nivolumab and Ipilimumab in Advanced Melanoma. N. Engl. J. Med. 2017, 377, 1345-1356. [CrossRef] [PubMed] 
73. Shivaji, U.N.; Jeffery, L.; Gui, X.; Smith, S.C.L.; Ahmad, O.F.; Akbar, A.; Ghosh, S.; Iacucci, M. Immune checkpoint inhibitor-associated gastrointestinal and hepatic adverse events and their management. Ther. Adv. Gastroenterol. 2019, 12. [CrossRef] [PubMed]

74. Simpson, T.R.; Li, F.; Montalvo-Ortiz, W.; Sepulveda, M.A.; Bergerhoff, K.; Arce, F.; Roddie, C.; Henry, J.Y.; Yagita, H.; Wolchok, J.D.; et al. Fc-dependent depletion of tumor-infiltrating regulatory T cells co-defines the efficacy of anti-CTLA-4 therapy against melanoma. J. Exp. Med. 2013, 210, 1695-1710. [CrossRef] [PubMed]

75. Arce-Vargas, F.; Furness, A.J.S.; Litchfield, K.; Joshi, K.; Rosenthal, R.; Ghorani, E.; Solomon, I.; Lesko, M.H.; Ruef, N.; Roddie, C.; et al. Fc Effector Function Contributes to the Activity of Human Anti-CTLA-4 Antibodies. Cancer Cell 2018, 33, 649-663. [CrossRef] [PubMed]

76. Korman, A.J.; Engelhardt, J.; Loffredo, J.; Valle, J.; Akter, R.; Vuyyuru, R.; Bezman, N.; So, P.; Graziano, R.; Tipton, K.; et al. Abstract SY09-01: Next-Generation Anti-CTLA-4 Antibodies; AACR: Philadelphia, PA, USA, 2017; Volume 77.

77. Pereira, N.A.; Chan, K.F.; Lin, P.C.; Song, Z. The "less-is-more" in therapeutic antibodies: Afucosylated anti-cancer antibodies with enhanced antibody-dependent cellular cytotoxicity. MAbs 2018, 10, 693-711. [CrossRef] [PubMed]

78. Price, K.D.; Simutis, F.; Fletcher, A.; Ramaiah, L.; Srour, R.; Kozlosky, J.; Sathish, J.; Engelhardt, J.; Capozzi, A.; Crona, J.; et al. Abstract LB-B33: Nonclinical Safety Evaluation of Two Distinct Second Generation Variants of Anti-CTLA4 Monoclonal Antibody, Ipilimumab, in Monkeys; AACR: Philadelphia, PA, USA, 2018; Volume 17.

79. Goletz, C.; Lischke, T.; Harnack, U.; Schiele, P.; Danielczyk, A.; Rühmann, J.; Goletz, S. Glyco-engineered anti-human programmed death-ligand 1 antibody mediates stronger CD8 $\mathrm{T}$ cell activation than its normal glycosylated and non-glycosylated counterparts. Front. Immunol. 2018, 9, 1614. [CrossRef]

80. Okada, M.; Chikuma, S.; Kondo, T.; Hibino, S.; Machiyama, H.; Yokosuka, T.; Nakano, M.; Yoshimura, A. Blockage of core fucosylation reduces cell-surface expression of PD-1 and promotes anti-tumor immune responses of T cells. Cell Rep. 2017, 20, 1017-1028. [CrossRef]

81. Wong, C.; Mei, L.; Wong, K.R.; Menendez, E.E.; Vasiljeva, O.; Richardson, J.H.; West, J.W.; Kavanaugh, M.; Irving, B.A. Abstract A081: A PD-L1-targeted Probody provides antitumor efficacy while minimizing induction of systemic autoimmunity. Cancer Immunol. Res. 2016, 4, A081. [CrossRef]

82. Autio, K.A.; Boni, V.; Humphrey, R.W.; Naing, A. Probody Therapeutics: An Emerging Class of Therapies Designed to Enhance On-target Effects with Reduced Off-tumor Toxicity for Use in Immuno-Oncology. Clin. Cancer. Res. 2019. [CrossRef]

83. Fromm, G.; de Silva, S.; Johannes, K.; Patel, A.; Hornblower, J.C.; Schreiber, T.H. Agonist redirected checkpoint, PD1-Fc-OX40L, for cancer immunotherapy. J. Immunother. Cancer 2018, 6, 149. [CrossRef] [PubMed]

84. Kvarnhammar, A.M.; Veitonmaki, N.; Hagerbrand, K.; Smith, K.E.; Fritzell, S.; Johansson, M. The CTLA-4 x OX40 bispecific antibody ATOR-1015 induces anti-tumor effects through tumor-directed immune activation. J. Immunother. Cancer 2019, 7, 103. [CrossRef] [PubMed]

85. Lacey, D.L.; Boyle, W.J.; Simonet, W.S.; Kostenuik, P.J.; Dougall, W.C.; Sullivan, J.K.; San-Martin, J.; Dansey, R. Bench to bedside: Elucidation of the OPG-RANK-RANKL pathway and the development of denosumab. Nat. Rev. Drug Discov. 2012, 11, 401-419. [CrossRef] [PubMed]

86. Ahern, E.; Smyth, M.J.; Dougall, W.C.; Teng, M.W.L. Roles of the RANKL-RANK axis in antitumour immunity-Implications for therapy. Nat. Rev. Clin. Oncol. 2018, 15, 676-693. [CrossRef]

87. Dougall, W.C.; Roman Aguilera, A.; Smyth, M.J. Dual targeting of RANKL and PD-1 with a bispecific antibody improves anti-tumor immunity. Clin. Transl. Immunol. 2019, 8, e01081. [CrossRef]

88. Lan, Y.; Zhang, D.; Xu, C.; Hance, K.W.; Marelli, B.; Qi, J.; Yu, H.; Qin, G.; Sircar, A.; Hernández, V.M.; et al. Enhanced preclinical antitumor activity of M7824, a bifunctional fusion protein simultaneously targeting PD-L1 and TGF-beta. Sci. Transl. Med. 2018, 10, eaan5488. [CrossRef]

89. Knudson, K.M.; Hicks, K.C.; Luo, X.; Chen, J.Q.; Schlom, J.; Gameiro, S.R. M7824, a novel bifunctional anti-PD-L1/TGFbeta Trap fusion protein, promotes anti-tumor efficacy as monotherapy and in combination with vaccine. Oncoimmunology 2018, 7, e1426519. [CrossRef]

90. LaMotte-Mohs, R.; Shah, K.; Smith, D.; Gorlatov, S.; Ciccarone, V.; Tamura, J.; Li, H.; Smith, D.; Rillema, J.; Licea, M.; et al. Abstract 3217: MGD013, a bispecific PD-1 x LAG-3 Dual-Affinity Re-Targeting (DART®) protein with T-cell immunomodulatory activity for cancer treatment. Cancer Res. 2016, 76. [CrossRef] 
91. Huang, R.Y.; Eppolito, C.; Lele, S.; Shrikant, P.; Matsuzaki, J.; Odunsi, K. LAG3 and PD1 co-inhibitory molecules collaborate to limit CD8+ T cell signaling and dampen antitumor immunity in a murine ovarian cancer model. Oncotarget 2015, 6, 27359-27377. [CrossRef]

92. US Patent Application, 2013. 2019. Available online: https://patentimages.storage.googleapis.com/8b/4d/30/ d6e970eabaafe5/US20130022629A1.pdf (accessed on 20 November 2019).

93. United States Patent, 2017. 2019. Available online: https://patentimages.storage.googleapis.com/be/e6/87/ 848fb505a78c89/US9850225.pdf (accessed on 20 November 2019).

94. Zak, K.M.; Grudnik, P.; Guzik, K.; Zieba, B.J.; Musielak, B.; Dömling, A.; Holak, T.A. Structural basis for small molecule targeting of the programmed death ligand 1 (PD-L1). Oncotarget 2016, 7, 30323-30335. [CrossRef]

95. Incyte Corporation Heterocyclic Compounds as Immunomodulators United States Patent 2017. 2019. Available online: https://patentimages.storage.googleapis.com/71/16/5d/4faf7b71faf81b/WO2017087777A1. pdf (accessed on 20 November 2019).

96. Lazorchak, A.S.; Patterson, T.; Ding, Y.; Sasikumar, P.G.; Sudarshan, N.S.; Gowda, N.M.; Ramachandra, R.K.; Samiulla, D.S.; Giri, S.; Eswarappa, R.; et al. Abstract A36: CA-170, An Oral Small Molecule PD-L1 and VISTA Immune Checkpoint Antagonist, Promotes T Cell Immune Activation and Inhibits Tumor Growth in Pre-Clinical Models of Cancer; AACR: Philadelphia, PA, USA, 2017; Volume 5. [CrossRef]

97. Pharmacodynamic effects of CA-170, a First-in-Class Small Molecule Oral Immune Checkpoint Inhibitor (ICI) Dually Targeting V-Domain Ig Suppressor of T-cell Activation (VISTA) and PDL1. 2018. Available online: http://www.curis.com/images/stories/pdfs/posters/SITC2018CA-170RPD961.pdf (accessed on 12 August 2019).

98. Phase 2 trial of CA-170, a Novel Oral Small Molecule Dual Inhibitor of Immune Checkpoints VISTA and PD-1, in Patients with Advanced Solid Tumor and Hodgkin Lymphoma. Available online: http: //www.curis.com/images/stories/pdfs/posters/SITC2018CA-170P714ASIAD.pdf (accessed on 12 August 2019).

99. Musielak, B.; Kocik, J.; Skalniak, L.; Magiera-Mularz, K.; Sala, D.; Czub, M.; Plewka, J. CA-170—A Potent Small-Molecule PD-L1 Inhibitor or Not? Molecules 2019, 24, 2804. [CrossRef] [PubMed]

100. Chang, H.N.; Liu, B.Y.; Qi, Y.K.; Zhou, Y.; Chen, Y.P.; Pan, K.M.; Qi, Y.M. Blocking of the PD-1/PD-L1 Interaction by a D-Peptide Antagonist for Cancer Immunotherapy. Angew. Chem. Int. Ed. 2015, 54, 11760-11764. [CrossRef] [PubMed]

101. Boohaker, R.J.; Sambandam, V.; Segura, I.; Miller, J.; Suto, M.; Xu, B. Rational design and development of a peptide inhibitor for the PD-1/PD-L1 interaction. Cancer Lett. 2018, 434, 11-21. [CrossRef] [PubMed]

102. Magiera-Mularz, K.; Skalniak, L.; Zak, K.M.; Musielak, B.; Rudzinska-Szostak, E.; Berlicki, Ł.; Shaabani, S. Bioactive Macrocyclic Inhibitors of the PD-1/PD-L1 Immune Checkpoint. Angew. Chem. Int. Ed. 2017, 56, 13732-13735. [CrossRef]

103. Li, C.; Zhang, N.; Zhou, J.; Ding, C.; Jin, Y.; Cui, X.; Zhu, Y. Peptide Blocking of PD-1/PD-L1 Interaction for Cancer Immunotherapy. Cancer Immunol. Res. 2018, 6, 178-188. [CrossRef]

104. AUNP-12-A Novel Peptide Therapeutic Targeting PD-1 Immune Checkpoint Pathway for Cancer Immunotherapy—Structure Activity Relationships \& Peptide/Peptidomimetic Analogs. 2014. Available online: http://www.differding.com/page/aunp_12_a_novel_peptide_therapeutic_targeting_pd_1_immune_ checkpoint_pathway_for_cancer_immunotherapy/f1.html (accessed on 14 August 2019).

105. Sasikumar, P.; Shrimali, R.; Adurthi, S.; Ramachandra, R.; Satyam, L.; Dhudashiya, A.; Ramachandra, M. A novel peptide therapeutic targeting PD1 immune checkpoint with equipotent antagonism of both ligands and a potential for better management of immune-related adverse events. J. Immunother. Cancer 2013, 1, 24. [CrossRef]

106. Sasikumar, P.G.; Ramachandra, R.K.; Adurthi, S.; Dhudashiya, A.A.; Vadlamani, S.; Vemula, K.; Vunnum, S.; Satyam, L.K.; Samiulla, D.S.; Subbarao, K.; et al. A Rationally Designed Peptide Antagonist of the PD-1 Signaling Pathway as an Immunomodulatory Agent for Cancer Therapy. Mol. Cancer Ther. 2019, 18, 1081-1091. [CrossRef]

(C) 2019 by the authors. Licensee MDPI, Basel, Switzerland. This article is an open access article distributed under the terms and conditions of the Creative Commons Attribution (CC BY) license (http://creativecommons.org/licenses/by/4.0/). 